В.О. Маланчук', І.С. Бродецький', М.С. Кротевич ${ }^{2}$ ${ }^{1}$ Національний медичний університет імені О.О. Богомольця, Київ ${ }^{2}$ Національний інститут раку, Київ

\title{
Імуногістохімічні показники деяких видів вірусів серед доброякісних пухлин слинних залоз
}

Мета - виявлення етіологічних факторів розвитку доброякісних пухлин слинних залоз (СЗ) серед деяких груп вірусів. Об'єкт і методи дослідження. Гістологічне типування новоутворень Сз проведено з використанням забарвлення гематоксиліном і еозином та імуногістохімічного дослідження. Дослідження проведено на матеріалі ексцизійних біопсій СЗ (плеоморфних аденом, аденолімфом) у 32 пацієнтів. Імуногістохімічне дослідження проводили з моноклональним мишиним антитілом - Monoclonal mouse anti-Epstein - Barr virus, LMP, clones CS. 1-4 («Dako» IS75330-2, Данія), з поліклональним кролячим антитілом - Polyclonal rabbit antibody p16 (CDKN2A) («Thermo scientific» PAL. 16662) з використанням системи детекції «EnVision ${ }^{T M}$ FLEX System». Для позитивного контролю використовували тканинні зразки з визначеною позитивною реактивністю, для негативного - проводили процедуру без застосування первинних антитіл. Результати. У більшості хворих із плеоморфними аденомами була уражена привушна С3. Серед вірусів, наявних у тканинах пухлини привушної СЗ, у 19 (67,9\%) хворих домінував ВПЛ 16 та у 8 (28,6\%) - вірус Епштейна - Барр (ВЕБ). ВПЛ 16 виявлено у $4(100,0 \%)$ пацієнтів із аденолімфомами СЗ. Висновки. У більшості пацієнтів, в яких виявлені позитивні реакції на експресію рецепторів до ВПЛ 16 та ВЕБ, новоутворення локалізувались у привушних СЗ. Більшість позитивних реакцій серед плеоморфних аденом та аденолімфом СЗ були на ВПЛ $16-21$ (75,0\%) та 4(100,0\%) відповідно.

Ключові слова: пухлини слинних залоз, плеоморфна аденома, аденолімфома, імуногістохімічне дослідження, вірус папіломи людини 16-го типу, вірус Епштейна - Барр.

\section{Вступ}

Питання щодо етіології пухлин людини залишається актуальним вже тривалий час. Серед основних факторів ризику пухлиногенезу виділяють фізичні (довготривалий вплив холоду, тепла, іонізуючого випромінювання), хімічні (бензпірен, нітрати та ін.), біологічні (різні види вірусів). Окремо існують теорії розвитку пухлин - мутаційна, генетична, імунна тощо (Маланчук В.О. (ред.), 2011a; б). Завдяки вивченню факторів ризику і теорій розвитку пухлин науковці намагаються пояснити механізм розвитку більшості новоутворень людини та створити адекватні методи діагностики, лікування і профілактики цих патологічних процесів.

Одними з поширених та дискусійних пухлин в ділянці голови та шиї залишаються новоутворення слинних залоз (СЗ), які становлять 1-5\% усіх новоутворень людини (Пачес А.И. (ред.), 2009). Серед найпоширеніших доброякісних пухлин СЗ виокремлюють плеоморфні аденоми (ПА) (61-90\%) та аденолімфоми (АЛ) (1530\%) (Da Silva L.P. et al., 2018).

Впровадження нових методів діагностики серед пухлин С3 дозволяє виявити додаткові етіологічні фактори розвитку цих новоутворень (вірусна залежність). Одним зі стандартів у діагностиці пухлин різного походження залишається імуногістохімічне дослідження (ІГХД).

Кількість імуногістохімічних маркерів пухлин збільшується з кожним роком, що розширює діагностичні можливості цього методу та дозволяє створювати нові схеми в лікуванні злоякісних пухлин (Prichard J.W., 2014).

Вплив вірусів на розвиток різних видів пухлин вже достатньо вивчений. Зокрема відомо про роль вірусу папіломи людини (ВПЛ) 6-го, 8-го, 16-го (ВПЛ 16), 18-го (ВПЛ 18) типу у розвитку раку шийки матки (Chen L.P. et al., 1991). Незважаючи на наявність значної кількості наукових праць, присвячених впливу вірусів на розвиток пухлин, питання щодо виявлення цих факторів у тканинах СЗ вивчені недостатньо чи на статистично малій кількості хворих.

Мета - виявлення етіологічних факторів розвитку доброякісних пухлин СЗ (ПА, АЛ) серед деяких груп вірусів.

\section{Об'єкт і методи дослідження}

Гістологічне типування новоутворень СЗ проведено з використанням рутинного забарвлення гематоксиліном і еозином та ІГХД.

Дослідження проведено на матеріалі ексцизійних біопсій С3 (ПА, АЛ) у 32 пацієнтів. Для дослідження проведено забір пухлини з видаленої привушної (ПСЗ) та підщелепної С 3 розміром 10х10 мм, товщиною до 4 мм. Вирізані шматочки пухлини вкладали у касети і за допомогою тримача для касет розміщували їх на 16 год у ємкості для фіксації у забуференому 10\% розчині формаліну з рН 7,4. Ущільнювали матеріал у парафіні із застосуванням гістіопроцесора «HISTOS-5» («Milestone», Італія) за програмою для операційного матеріалу -4 мм. Після завершення програми просочення в парафіні касети виймали з парафінового блоку гістіопроцесора і на станції для заливки «TEC 2800 Embedding Center» шматочки тканин заливали розплавленим парафіном у формочки з подальшим застиганням на холодильному модулі станції «ТЕС 2800-C Cryo Console». 3 отриманих парафінових блоків виготовляли гістологічні зрізи товщиною 5 мкм задопомогою мікротома «MICROM HM325» («Thermo Fisher Scientific», Німеччина). Зрізи забарвлювали гематоксиліном і еозином для патогістологічного дослідження пухлини, морфометрії та підрахунку об'єму життєздатної пухлинної тканини.

ІГХД проводили з моноклональним мишиним антитілом Monoclonal mouse anti-Epstein - Barr virus, LMP, clones CS. 1-4 («Dako» IS75330-2, Данія), з поліклональним кролячим антитілом - Polyclonal rabbit antibody р16 (CDKN2A) («Thermo scientific» PAL. 16662) з використанням системи детекції «EnVision ${ }^{\mathrm{TM}}$ FLEX System» («Dako», Данія). Демаскування антигену проводили в цитратному буфері з $\mathrm{pH} 6,0$ за температури $95^{\circ} \mathrm{C}$. Первинні антитіла інкубували при кімнатній температурі протягом 30 хв, вторинні протягом 20 хв. Зрізи дофарбовували гематоксиліном Gill. Для позитивного контролю використовували тканинні зразки з визначеною позитивною реактивністю, для негативного - проводили процедуру без застосування первинних антитіл.

Отримані препарати вивчали та фотографували за допомогою мікроскопа «OLYMPUS CX41» 3 камерою та програмним забезпеченням «QuickPHOTO MICRO 2.3» за стандартизованих умов. 
Результати та їх обговорення

Аналіз даних, представлених утабл. 1, показав, що у більшості хворих з ПА ураженню підлягала ПСЗ. Серед вірусів, наявних у тканинах пухлини ПСЗ, у 19 (67,8\%) пацієнтів домінував ВПЛ 16 , у $8(28,6 \%)$ - вірус Епштейна - Барр (ВЕБ).

Таблиця 1. Імуногістохімічні показники різних типів вірусів серед ПА різних видів С3, n (\%)

\begin{tabular}{lcccc}
\hline \multicolumn{1}{c}{ Показник ІГХД } & ПС3 & $\begin{array}{c}\text { Підщелепна } \\
\text { С3 }\end{array}$ & $\begin{array}{c}\text { Під'язична } \\
\text { С3 }\end{array}$ & Малі C3 \\
\hline ВЕБ & $8(28,6)$ & - & - & - \\
ВПЛ 16 & $19(67,8)$ & $1(3,6)$ & - & $1(3,6)$ \\
Загальна кількість обстежених & & Позитивний у 27 хворих & \\
хворих 3 ПА -28 & & &
\end{tabular}

У одного хворого показник був негативний. При підрахунку враховували, що у одного хворого були позитивними одразу декілька імуногістохімічних показників.

Таблиця 2. Показники ІГХД для ПА СЗ ( $\mathrm{n}=28)$

\begin{tabular}{lcc}
\hline \multicolumn{1}{c}{ Показники ІГХД } & \multicolumn{2}{c}{ Кількість } \\
\cline { 2 - 3 } & абсолютна, $\mathbf{n}$ & відносна, \% \\
\hline ВЕБ & 8 & 28,6 \\
ВПЛ 16 & 21 & 75,0 \\
Загальна кількість обстежених хворих з аденомою & 28 & 100,0 \\
\hline При підрахунку враховували, що у одного хворого були позитивними одразу декілька \\
імуногістохімічних показників.
\end{tabular}

При підрахунку імуногістохімічних показників ПА різних видів СЗ спостерігали підвищення показника ВПЛ 16 до 75\% (рис. 1, 2).

Таблиця 3. Показники ІГХД для АЛ С3 ( $\mathrm{n}=4)$

\begin{tabular}{lccc}
\hline \multicolumn{1}{c}{ Показники ІГХД } & \multicolumn{2}{c}{ Кількість } \\
\cline { 2 - 3 } & абсолютна, $\mathbf{n}$ & відносна, \% \\
\hline ВЕБ & 1 & 25,0 \\
ВПЛ 16 & 4 & 100,0 \\
Загальна кількість обстежених хворих з аденомою & 4 & 100,0 \\
\hline
\end{tabular}

При підрахунку враховували, що у одного хворого були позитивними одразу декілька імуногістохімічних показників. Локалізація АЛ в усіх чотирьох випадках - у ПСЗ.

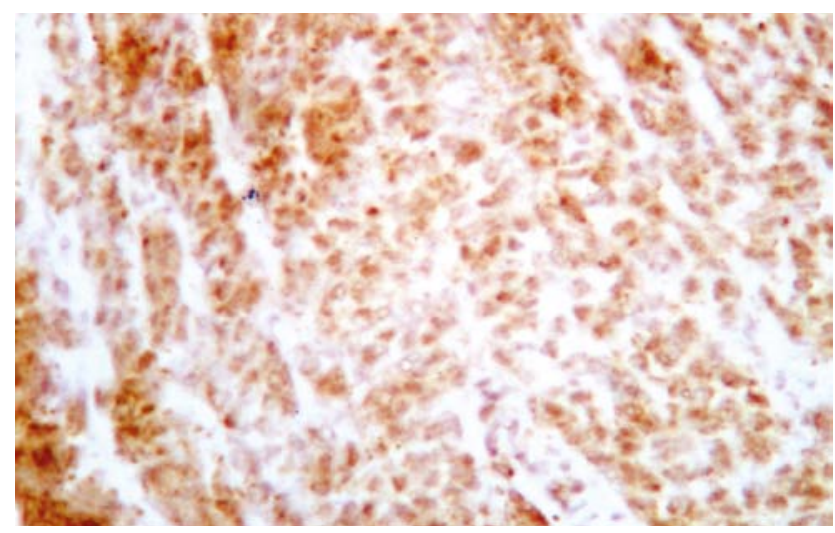

Рис. 1. Фото гістопрепарату тканин ПА привушної СЗ пацієнта Л., 33 років. 3б. $x$ 200. Позитивна ядерно-цитоплазматична імуногістохімічна реакція (ІГХР) на ВПЛ 16

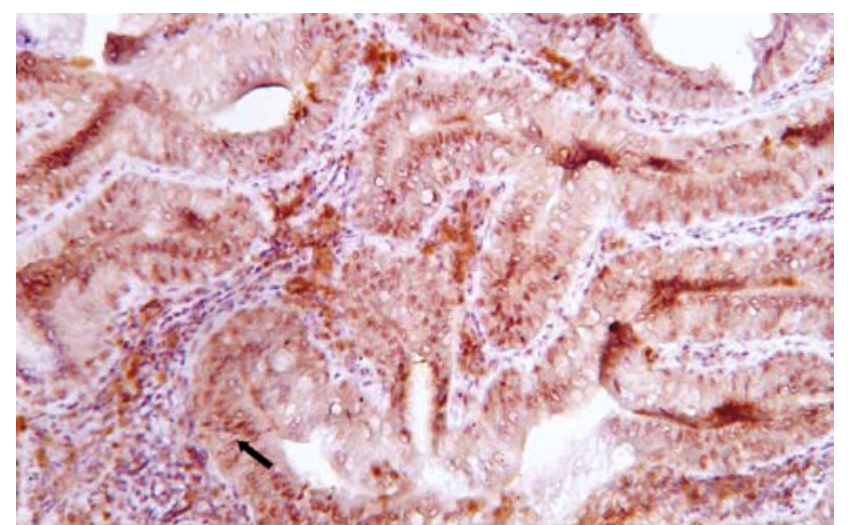

Рис. 3. Фото гістопрепарату тканин АЛ привушної С3 пацієнта 3., 53 років. 3б. х 200. Позитивна ядерно-цитоплазматична ІГХР на ВПЛ 16 (позначено стрілкою)
Аналіз даних табл. 3 показав, що серед АЛ СЗ домінував ВПЛ $16-4(100,0 \%)$ (рис. 3, 4).

Таблиця 4. Імуногістохімічні показники вірусів для ПА С3 (n=28), n (\%)

\begin{tabular}{cccc}
\hline \multicolumn{3}{c}{ Позитивна реакція } & $\begin{array}{c}\text { Негативна } \\
\text { реакція }\end{array}$ \\
\hline $\begin{array}{c}\text { Моновірус } \\
\text { ВПЛ 16 }\end{array}$ & Моновірус ВЕБ & ВПЛ 16 + ВЕБ & ВПЛ 16 + ВЕБ \\
$15(53,6)$ & $2(7,1)$ & $6(21,4)$ & $5(17,8)$ \\
\hline
\end{tabular}

При підрахунку ІГХР на віруси ВПЛ 16 та ВЕБ серед ПА СЗ встановлено три типи позитивних реакцій: на моновірус ВПЛ $16-$ $15(53,6 \%)$, моновірус ВЕБ - $2(7,1 \%)$ та ВПЛ $16+$ ВЕБ $-6(21,4 \%)$. Негативну реакцію на ВПЛ 16 + ВЕБ спостерігали у $5(17,8 \%)$ пацієнтів.

Таблиця 5. Імуногістохімічні показники вірусів для АЛ С3 (n=4), n (\%)

\begin{tabular}{cccc}
\hline & Позитивна реакція & & $\begin{array}{c}\text { Негативна } \\
\text { реакція }\end{array}$ \\
\hline Моновірус & Моновірус ВЕБ & ВПЛ 16+ ВЕБ & ВПЛ 16 + ВЕБ \\
ВПЛ 16 & - & $1(25,0)$ & - \\
$3(75,0)$ & - & В
\end{tabular}

При підрахунку ІГХР на віруси ВПЛ 16 та ВЕБ серед АЛ С3 встановлено два типи позитивних реакцій: на моновірус ВПЛ $16-$ у 3 (75,0\%), ВПЛ 16 + ВЕБ - у 1 (25,0\%) пацієнта.

Вплив вірусної інфекції на розвиток пухлин достатньо відомий. Більшість із них відіграють значну роль в етіології як доброякісних, так і злоякісних пухлин. Серед найвідоміших вірусних агентів ВПЛ, ВЕБ, цитомегаловірус, віруси гепатиту В і С, вірус герпесу різних типів. ВПЛ, цитомегаловірус та вірус простого герпесу чинять значний вплив на розвиток раку шийки матки (Laane C.J. et al., 2002; Lin F.C.F. et al., 2014). ВПЛ спричиняє розвиток різних видів орофарингеальних, гіпо- та назофарингеальних карцином та немеланомного раку шкіри. Віруси гепатиту В $\mathrm{C}$, , асоційований із саркомою Капоші герпесвірус беруть участь у розвитку різних видів гепатоцелюлярного раку (Müller-Coan B.G. et al., 2018). ВЕБ у більшості випадків спричиняє розвиток лімфоцитасоційованих

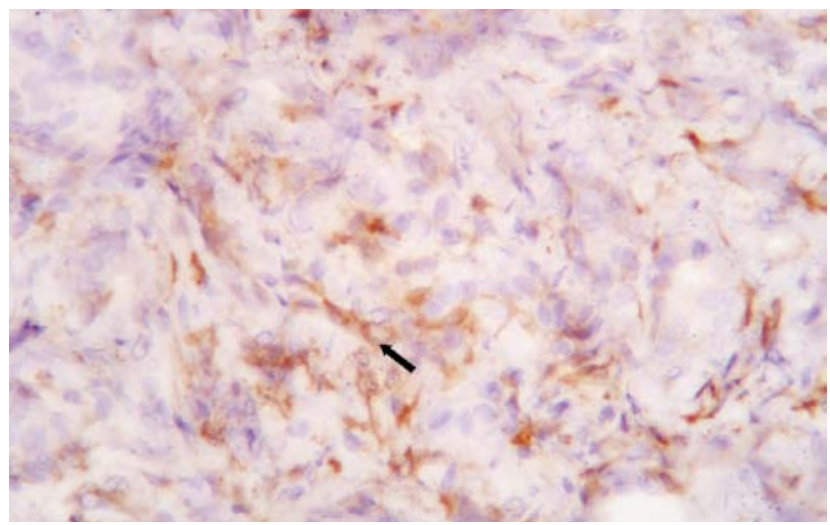

Рис. 2. Фото гістопрепарату тканин ПА привушної СЗ пацієнта П., 23 років. 3б. x 200. Позитивна мембрано-цитоплазматична ІГХР на ВЕБ (позначено стрілкою)

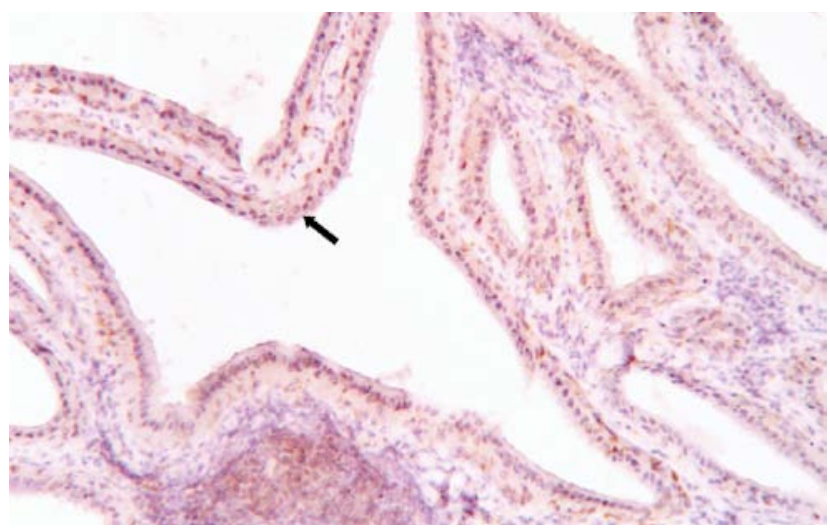

Рис. 4. Фото гістопрепарату тканин аденолімфоми привушної С3 пацієнта 3., 53 років. Зб. х 200. Слабопозитивна мембрано-цитоплазматична ІГХР на ВЕБ (позначено стрілкою) 
пухлин, зокрема лімфом (Laane C.J. et al., 2002). Також встановлено взаємозв'язок між деякими вірусами (ретровірус активується асоційованим із саркомою Капоші герпесвірусом та ВЕБ) та ї можливістю взаємно активувати і посилювати активність один одного і таким чином спричиняти розвиток пухлин із подальшим канцерогенезом (Chen J. et al., 2019).

СЗ як орган, що, окрім слиновидільної, виконує ендокринну та імунну функції, достатньо часто зазнає ураження з боку різних вірусів із подальшим розвитком пухлинного процесу. Більшість науковців описують ІГХДПА, АЛ та аденокарцином, де серед основних вірусних агентів виявляють ВПЛ 16, ВПЛ 18 та ВЕБ (Hühns M. et al. 2015; Miah M.S. etal., 2015). Так, серед ПА 33-39\% мають позитивну реакцію на ВПЛ 16 та 7\%- ВЕБ, а серед АЛ - 33 та 22\% відповідно (Lin F.C.F. et al., 2014; Hühns M. et al., 2015; Miah M.S. et al., 2015). Існують окремі роботи, в яких зазначають відсутність вірусів ВПЛ, ВЕБ у тканинах пухлин та вітальних СЗ, або незначну і статистично недостовірну частку спостережень, що ставить під сумнів вплив цих видів вірусних патогенів на розвиток пухлин СЗ (Skálová A. et al., 2013).

Проведені нами ІГХД парафінних блоків від видалених пухлин С3 (ПА, АЛ) свідчать про домінування ВПЛ $16-$ у 21 (75,0\%) та ВЕБ - у 8 (28,6\%) випадків ПА та ВПЛ 16 - у 4 (100,0\%) і ВЕБ у $1(25,0 \%)$ випадків АЛ. Проводячи порівняння отриманих даних з доступними науковими джерелами, можна зробити висновок, про підвищення поширеності вірусу ВПЛ 16 та ВЕБ у тканинах пухлин С3, а отже, їхня роль у розвитку пухлин не викликає сумнівів.

Таким чином, можна достовірно стверджувати, що одна зі значних ланок пухлинного процесу в тканинах СЗ належить вірусам ВПЛ 16 та ВЕБ.

\section{Висновки}

1. Серед доброякісних пухлин СЗ (ПА, АЛ) характерна експресія рецепторів до ВПЛ 16 та ВЕБ.

2. У більшості пацієнтів, в яких виявлено позитивні реакції на експресію рецепторів до ВПЛ 16 та ВЕБ, новоутворення локалізувались у ПСЗ.

3. Серед пацієнтів із ПА СЗ відзначали експресію рецепторів до ВПЛ 16 у 21 (75,0\%), ВЕБ - у 8 (28,6\%). Серед осіб із АЛ ВПЛ 16 виявлено у 4 (100,0\%), ВЕБ - у 1 (25,0\%).

4. Серед пацієнтів із ПА СЗ домінувала позитивна ІГХР на моновірус ВПЛ 16 - у $15(53,6 \%)$ та ВПЛ 16 + ВЕБ - у $6(21,4 \%)$.

5. Серед АЛ СЗ домінувала позитивна ІГХР на моновірус ВПЛ 16 - у $3(75,0 \%)$, ВПЛ 16 + ВЕБ - у 1 (25,0\%).

\section{Список використаної літератури}

Маланчук В.О. (ред.) (2011a) Хірургічна стоматологія та щелепно-лицева хірургія. Т. 1, Логос, Київ, 627 с.

Маланчук В.О. (ред.) (2011б) Хірургічна стоматологія та щелепно-лицева хірургія. Т. 2, Логос, Київ, 606 с. $470 \mathrm{c}$.

Пачес А.И. (ред.) (2009) Опухоли слюнных желез: Практ. медицина, Москва

Chen J., Foroozesh M., Qin Z. (2019) Transactivation of human endogenous retroviruses by tumor viruses and their functions in virus-associated malignancies. Oncogenesis, 8(1): 6

Chen L.P., Thomas E.K., Hu S.L. et al. (1991) Human papillomavirus type 16 nucleoprotein E7 is a tumor rejection antigen. Proc. Natl. Acad. Sei. USA, 88(1): $110-114$.

Da Silva L.P., Serpa M.S., Viveiros S.K. et al. (2018) Salivary gland tumors in a Brazilian population: a 20-year retrospective and multicentric study of 2292 cases. J. Craniomaxillofac. Surg., 46(12): 2227-2233.

Hühns M., Simm G., Erbersdobler A., Zimpfer A. (2015) HPV infection, but not EBV or HHV-8 infection, is associated with salivary gland tumours. BioMed. Res. Int., 1-7.

Laane C.J., Murr A.H., Mhatre A.N. et al. (2002) Role of Epstein - Barr virus and cytomegalovirus in the etiology of benign parotid tumors. Head Neck, 24(5): $443-450$.

Lin F.C.F., Chen P.L., Tsao T.Y. et al. (2014) Prevalence of human papillomavirus and Epstein - Barr virus in salivary gland diseases. J. Int. Med. Res., 42(5): 1093-1101.

Miah M.S., Majumdar S., White S. et al. (2015) Human papillomavirus and salivary gland neoplasia: a p16INK4 immunohistochemical and in situ hybridisation study. J. Laryngol. Otol., 129(10): 1000-1003.

Müller-Coan B.G., Caetano B.F.R., Pagano J.S., Oliveira E.D.E. (2018) Cancer progression goes viral: the role of oncoviruses in aggressiveness of malignancies. Trends Cancer, 4(7): 485-498.

Prichard J.W. (2014) Overview of automated immunohistochemistry. Arch Pathol. Lab. Med.,138(12): 1578-1582.
Skálová A., Kašpirková J., Andrle P. et al. (2013) Human papillomaviruses are not involved in the etiopathogenesis of salivary gland tumors. Cesk. Patol., 49(2): 72-75.

\section{Иммуногистохимические показатели некоторых видов вирусов среди доброкачественных опухолей слюнных желез}

\section{В.А. Маланчук, И.С. Бродецкий, М.С. Кротевич}

Резюме. Цель - выявление этиологических факторов развития доброкачественных опухолей слюнных желез (СЖ) среди некоторых групп вирусов. Объекти методы исследования. Гистологическое типирование новообразований СЖ проведено с использованием окраски гематоксилином и эозином и иммуногистохимического исследования. Исследование проведено на материале эксцизионных биопсий СЖ (плеоморфных аденом, аденолимфом) у 32 пациентов. Иммуногистохимическое исследование проводили с моноклональным мышиным антителом - Monoclonal mouse anti-Epstein - Barr virus, LMP, clones CS. 1-4(«Dako» IS75330-2, Дания), с поликлональным кроличьим антителом - Polyclonal rabbitantibody p16(CDKN2A) ("Thermo scientific»PAL. 16662) с использованием системы детекции «EnVision ${ }^{T M}$ FLEX System». Для положительного контроля использовали тканевые образцы с определенной положительной реактивностью, для отрицательного - проводили процедуру без применения первичных антител. Результаты. У большинства больных с плеоморфными аденомами была поражена околоушная СЖ. Среди вирусов, присутствовавших в тканях опухоли околоушной СЖ, у 19 (67,8\%) пациентов доминировал ВПЧ 16 , y 8(28,6\%) - вирус Эпштейна - Барр (ВЭБ). Среди аденолимфом СЖ ВПЧ 16 отмечен в 4(100,0\%) случаях. Выводы. Убольшинства пациентов с положительными реакциями на экспрессию рецепторов к ВПЧ 16 и ВЭБ новообразования локализовались в околоушных СЖ. Большинство положительныхреакций среди плеоморфныхаденом и аденолимфом СЖ были на ВПЧ 16 - 21 (75,0\%) и 4(100,0\%) соответственно.

Ключевые слова: опухоли слюнных желез, плеоморфная аденома, аденолимфома, иммуногистохимическое исследование, вирус папилломы человека 16-го типа, вирус Эпштейна - Барр.

\section{Immunohistochemical indices of some types of viruses among benign tumors of salivary glands}

\section{V.O. Malanchuk, I.S. Brodetskyi, M.S. Krotevych}

Summary. The purpose - identification of the etiological factors of development of benign tumors of the salivary glands(SG) among certain groups of viruses. Materials and methods. Histological typing of SG tumors was performed using coloration with hematoxylin and eosin and immunohistochemical analysis. The study was conducted based on excision biopsies of SG (pleomorphic adenomas, adenolymphomas) in 32 patients. Immunohistochemical analysis was performed with Monoclonal mouse anti-Epstein - Barrvirus, LMP, clones CS. 1-4 («Dako» IS75330-2, Denmark), Polyclonal rabbit antibody p16 (CDKN2A) ( "Thermo scientific»PAL. 16662) using the "EnVision ${ }^{T M}$ FLEX System». For positive control tissue samples with definite positive reactivity were used, for negative - the procedure without the use of primary antibodies was performed. Results. The majority of patients with pleomorphic adenomas were affected in parotid SG. Among viruses that were presented in the tumor tissues of parotid SG in 19 (67.8\%) patients the HPV 16 and Epstein - Barr virus (EBV) - $8(28.6 \%)$ were dominated. Among SG adenolymphomas the HPV 16 dominated-4(100.0\%). Conclusions. In majority of patients who have been detected positive reactions to receptors expression against HPV 16 and EBVneoplasms were localized in parotidSG. For the most part of positive reactions among pleomorphic adenomas and adenolymphomas of SG to HPV 16 were $21(75.0 \%)$ and 4(100.0\%) respectively.

Key words: tumors of salivary glands, pleomorphic adenoma, adenolymphoma, immunohistochemistry analysis, human papillomavirus type 16, Epstein - Barr virus.

\section{Адреса для листування:}

Маланчук Владислав Олександрович

03057, Київ, вул. Зоологічна, 1

Національний медичний університет імені 0.0. Богомольця, кафедра хірургічної стоматології та щелепно-лицевої хірургії E-mail: mioche@ukr.net 